\title{
Transforming corporate governance through effective corporate social responsibility (CSR) and social entrepreneurship orientation in Nepal
}

\section{Authors \\ Seeprata Parajuli: aims to be enriched with depth knowledge on corporate management and transformation for sustainable development. pseeprata@gmail.com \\ Srijana Rajbhandari: an aspiring professional in the field of research and management development consultancy service. \\ Ashok Joshi: As a social entrepreneur, aims to work for the betterment of the society by addressing the impeding social issues and problems.}

Sujan K.C.: envisions as an entrepreneurial business person who strives for social welfare and generates solutions to societal problems and issues.

Udbodh Bhandari: Sociologist

\section{Key Words}

Corporate governance, corporate social responsibility, social entrepreneurship; transformation.

\begin{abstract}
Background: Different studies and development interventions have confirmed that socio-economic progress of a society is largely influenced by the exhibited level of corporate social responsibility (CSR) and social entrepreneurship orientation taken into account. This reality may serve in the same magnitude in context of present Nepalese corporate sector. However, different studies indicate that only a limited number of organizations are involved in such activities in the present context of Nepal. On the other hand, truthful participation with corporate social responsibility (CSR) related initiatives has been made mandatory in many countries thereby governing the CSR initiatives by defined rules and regulations.
\end{abstract}

Objectives: The thrust of this paper was to understand the magnitude and direction of CSR and social entrepreneurial orientation of the Nepalese corporate sector, its current state, issues, challenges and ways forward.

Methods: Accomplished on qualitative paradigm of study as a blend of guided literature reviews, seminar discourses and general situation observation and analyses, it may be claimed as a developmental discourse.

Results: The Nepalese corporate sector has been positively inclined towards enhancement of brand image, reputation and societal relationship by means of truthful engagement in CSR and societal entrepreneurship initiatives.

Conclusions: The attainment of socio-economic well-being can be witnessed by implementing effective CSR and social entrepreneurship initiatives. Insufficient preparedness of the public agencies with lack of follow-up, financing crises, traditional corporate policies and procedures have been the impeding issues affecting the design and execution of CSR and social entrepreneurship initiatives at present in Nepal.

Implications: Required strict policy regulations at governing level and effective programming at implementation at corporate or industry level.

Paper type: Review paper

For citation and referencing of this article:

Parajuli, S., Rajbhandari, S., Joshi, A., K.C., S. \& Bhandari, U. (2019). Transforming corporate governance through effective corporate social responsibility (CSR) and social entrepreneurship orientation in Nepal. Quest Journal of Management and Social Sciences: Corporate Governance Edition, 1(1), 26-49. Kathmandu: Quest Scientific Publications. 


\section{Introduction}

Though the concept of corporate social responsibility (CSR) seems to be prevailing since 1953 in business but it was the topic of debate, formal concept of CSR was developed in the 1960s and normally holds the social aspect and is referred directly to those responsibilities beyond economic and legal obligations (Waddock, 2004; Matten \& Crane, 2005) of the corporate entities. These scholars are of the uniform opinion that corporate responsibility consists of duties and responsibilities to carry institutional responsibilities in a society as organization, job creator, marketer, purchasers and the responsible personnel in an effective and efficient way. The responsibilities are carried out to fulfill the principles of the organization towards society and for the fulfillment of the government rules and legal provisions to create a positive impact of the organization in the society. The concept of corporate social responsibility has been an 'inescapable priority' in the society (Porter \& Kramer, 2006) or 'business virtue' which reflects the organization 'under a microscope' (Vogel, 2006). Many researches reflect corporate social responsibility (CSR) communication can enhance the trust and turn brand awareness among the customers to pay more prices for the product and services. Companies involved in CSR activities might have adequate tool to counter negative impact occurring in the company because of the awareness created among customers about the company (Vanhamme \& Grobben, 2009).

Ismail (2009) has concluded that CSR is the collaboration of business, government and society where all three entities will have win-win situation. Shah (2012) has figured that CSR is concerned with continuous commitment by business to behave ethically and contribute to economic development, while improving the quality of life of the workers and their families as well as that of the society at large so that company manages its business mechanism to produce an overall positive positioning on society. According to Welzel (2006), Nepalese companies can be divided into two ways in terms of CSR situation. The first is employee rights, such as written appointments for jobs, regular working hours and safety measurement such as part of supply chain and a second is the small or mid-sized, and family owned business such as private sectors ownership business. Corporate social responsibility (CSR) orientation is the key to stimulating long-term stability, growth and sustainable performance in a dynamic and changing environment (Jalilvand et al., 2017). Another scholar has opined that CSR is an important tool that helps to analyze the increasing rate of goodwill of the company and ultimately achieving profits to the company (Kandel, 2018).

Social enterprise is being a hyped as the economic mechanism of the future as well as a conceptual model for social responsibility (Manfredi, 2005). Social entrepreneurship involves the process of innovative and creative ideas to resolve social problems. Moreover, a social entrepreneur takes the initiative to create a value for the society. The continuous development of venture and learning are adopted to exploit the opportunities for societal development. Social entrepreneurship was first coined in 1980 by Bill Drayton of Ashoka that works as a global organization for social entrepreneurs around the world. In the situation where charitable and voluntary sectors are considered to be bureaucratic and intensity to change and the public sector has become over assumed and affected by the scarcity of the re- 
sources, social entrepreneurship (SE) has worked as the innovative way of providing solution to the societal problems (Leadbeater, 1997; Mulgan, \& Landry, 1995; as cited in Boporikar, 2015). Boporikar (2015) has mentioned innovate and creative activities have taken social entrepreneurship to various meaning on popular discourse as well as in the academic sectors. Entrepreneurship is the boarder concept to derive the concept of the social entrepreneurship and concludes entrepreneurship as the opportunities in the society that are to be achieved through the tangible resources.

Social entrepreneurship is emerging concern in today's global market attracting the interest of various groups (Bielefeld, 2009). Olinsson (2017) has expressed social entrepreneurship as key to solve social problems but the knowledge of social entrepreneurship seems lacking on entrepreneurs. Pathak et al. (2018) have concluded that social enterprise are perceived differently by different persons however, the major concept of social enterprise is to create positive and sustainable social impact rather than focusing on earning profits. Leadbeater (1997) has explained social entrepreneurship helps to find unutilized resources and try to put them to satisfy unmet social needs by innovating the way of delivering existing services. Value for social entrepreneurship can be attained in three forms: In short-run it can help in aiding to economy through employment creation, generating output or saving on public spending, in medium-run potential model for reform of the state with alliances with various sectors can be made. Similarly, in long-run they can create ability to create and invest social capital.

In relation to present work, the assessment was made regarding issues, challenges and way forward for corporate social responsibility, social entrepreneurship related contribution made by Nepalese corporate sector. Specifying the general objectives, the present study focuses to-

a. assess the present scenario of Nepalese corporate sector corporate social responsibility, social entrepreneurship initiatives,

b. examine the current problems of corporate sector for contributing in corporate social responsibility activities, social entrepreneurship initiations,

c. establish managerial implication for improving corporate sector contribution for corporate social responsibility, social entrepreneurship, and

d. analyze the impact of CSR activities in an organization in its overall business.

CG helps to facilitate and stimulate the performance of corporations by creating and maintaining incentives that motivate corporate insiders to maximize firms' operational efficiency, return on assets and long-term productivity growth. Similarly, the same scholar states that lack of CG limits insiders' abuse of power over corporate resources regarding abuses, which takes the form of insiders' asset stripping or otherwise siphoning off corporate resources for their private use, and/or, their causing significant wastage of corporate-controlled resources; also called the agency problems. Likewise, it helps to provide means to monitor managers' behavior to ensure corporate accountability and provide for reasonably cost-effective protection of investors' and society's interests (Oman, Fries \& Buiter, 2003). 
All the organization in the 21st century believes in the concept Socially Responsible Investment (SRI), to establish positive image among customers to control their wrong activities. Focusing on the SRI establishes the organization reach to be socially and financially successful. Organization performs corporate social responsibility for the growth and development of the business Sanitation is the secondary function (Ashley, 2012). CSR is not considered as the expenditure for the organization, but as strategic resources that enhances the performance and competitiveness of the corporation' (Chapagain, 2010). Corporate social responsibility is not to solve the world's problem but the capable companies can improve the life of the people by creating sustainable development opportunity in the society where it operates it business (Kandel, 2018). Baker (2004), CSR is about how companies manage the business processes for producing overall positive impact on society or state. Similarly, CSR should contribute for the development of society. In modern age company is a member of society, so they must have the responsibility toward the various stakeholders of the society.

Nepalese corporate sector have been trying but not efficiently been able to encourage the social entrepreneurial activities within the society and also prioritized the growth and development of the society through various societal promotion activities. The legal forms, organizational forms and academic definitions of social enterprises are quite diverse. Taking consideration of these factors the study has focused how efficient and effective is Nepalese corporate sector in the context of corporate social responsibility, social entrepreneurship.

Improving and initiating good corporate governance practice and policy is important for developing economies like Nepal which helps in reducing market vulnerability to financial crises, reinforces property rights and leads to capital market development. Whereas, weak corporate governance practice reduces investments, weakens investor's confidence and obstruct in development activities of the country. Till date no other formal corporate governance policies has been formulated by government except by NRB for banks and financial institutions in context of Nepal. However, Company Act, Security Act, BAFIA covers certain elements of corporate governance (Timalsina, 2015). So, this study aims to analyze and identify how corporate governance can be transformed through corporate social responsibility and social entrepreneurship.

The major concerns of the study that are used to justify objectives are:

a. What are the issues, challenges of corporate sectors for corporate social responsibility and social entrepreneurship initiation in Nepal?

b. How are the present practices of corporate social responsibility and social entrepreneurship in Nepalese corporate sector?

c. What are the possible ways to improve practices of corporate social responsibility and social entrepreneurship in Nepalese corporate sector?

d. How corporate social responsibility and social entrepreneurship can be applied managerially?

Nepalese corporate sectors have already experienced the practice of corporate social responsibility and social entrepreneurship. As such, it is felt significant to study the scenario, present conditions and way forward regarding CSR and social entrepreneurship and their prevalence in Nepalese corporate sector. 
Social responsibility is important factors in every organization. This study is expected to fill the research gap and add to inputs to Nepalese corporate sectors for the improvements in the fields. Moreover its significance can be in various sectors and some of them are identified during the course of the study.

Corporate social responsibility and social entrepreneurship are emerging and essential topic in Nepalese corporate sector. It may affect value of the firm. Moreover, most common objective of the firm is to maximize shareholder's and company's wealth. So, Companies should be able to conduct and cope along with these factors.

It can be used by researcher as guideline to fulfill the partial requirement of Master of Business Studies. It may help others who want to study in similar topic. Beside these it will also be beneficial for the policy makers, managers and organizations for considering corporate social responsibility and social entrepreneurship. They can get important findings, which are useful in policy making and also help customers, interested person and scholars.

Corporate social responsibility: Business Council for Sustainable Development (2002) has defined CSR as contribution towards sustainable economic development with the involvement of employees, stakeholders and society with business commitment. Welzel (2006) has explained CSR as a concept to solve social problems which would also help in strengthening core business activities.

Corporate governance: Naimah (2017) has elaborated corporate governance as way of directing, organizing and control the organization based on the pillars of transparency, responsibility, accountability, independence and fairness. Corporate governance includes ownership of responsibilities, duties and rights by different stake holders for pay of performance (Cornett, Marcus \& Tehranian, 2008).

Social entrepreneurship: Dees (2017) has described social entrepreneurship as role changer agent in social sector comprised to build sustainable social values with continuous improvement, adaptation and learning with accountability for required outcomes. Roberts \& Woods (2005) has termed social responsibility as construction, evaluation, search of new opportunities for social change.

This paper has been based on the qualitative analysis of relevant issues and exploratory research design. Formal and informal discussions were held with professors and relevant personalities for the purpose of information generation and evaluation and advice from experts had been taken for the completion of this paper. This study comprises all the information from secondary sources of data collection and do not include any of the primary sources.

\section{Review of literature}

This section of the paper deals with relevant concepts, principles and practices pertaining to effective design and implementation of corporate governance, CSR and social entrepreneurship initiatives, followed by development of relevant conceptual framework to govern the overall inquiry of interest. 


\section{Principles and practices of corporate governance}

Raut (2003) has stated corporate governance is the set of processes, customs, policies, laws, and institutions affecting the way a company is directed, administered or controlled and regulated. It also includes maintaining relationship with its stakeholders at various levels. Poor corporate governance can drive corporations to lose confidence, ineffectiveness and even invite risks (Macro \& Fernandez, 2009). Strong corporate governance might provide for better access to the capital and facilitate the economic growth and also has extensive organizational and social aspects similarly, good corporate governance ensures that the business environment is fair and transparent, and the organizations are accountable and good corporate governance might establish a sustainable and optimal business performance and ensures the social impact in the society (Al-Azzam et al., 2015). Corporate governance develops the management of an organization by strict monitoring and control, but environment is ever changing, CE presents modern and advanced methods to direct the organizations relative to goals of corporate governance (Bebchuk \& Weisbach, 2010). It is also based on prevention and supervision concepts and can be considered as corporate supervision and corporate control and based on the promotion of potential duty, it can further be considered as named corporate management or corporate governance (Ajina et al., 2015).

The concept of corporate governance is bound by various policies and principles under which all corporations should perform their duties. Some of the guiding principles have been presented briefly as follows:

Banking and Financial Institution Act (BAFIA) 2016: It is the umbrella act to govern all the banks and financial institutions in Nepal. The main objective of this act is to strengthen the banking and financial system of the country and promote the trust of general public in overall banking and financial system of the country. Similarly, this acts aims to protect and promote the rights and interests of the depositors, provide quality and reliable banking and financial intermediary service to the general public through healthy competition among banks and financial institutions. Nepal Rastra Bank (NRB) has formulated various directives, policies and regulations to safeguard banking and financial institutions and their operations. Amendment and consolidation in laws relating to banks and financial institutions like provision on incorporation of bank and financial institutions, provision on transaction of securities, provision for sale or pledging of securities, prohibition on transaction of shares, prohibition on purchase by bank and financial institution to its own share, conversion of promoter shares into public shares, provisions related to Board of Directors (formation), provision on merger and acquisition are made. Provisions related to independent directors for 'A' and 'B' class (national level) BFIs to graduate in respective track as prescribed by NRB. For 'B' (other except national level) and 'C' class BFIs undergraduate in respective subjects as prescribed by NRB. For ' $\mathrm{D}$ ' class BFIs qualification of independent directors as prescribed by NRB is required.

Banks for International Settlement (BASEL - 2014): Banks for international settlement (2014) has revealed that BASEL principle generally provides guidelines to banks on corporate governance. This principle has special emphasis on banks and provides guideline on 
internal control, audit and risk management of banks. It states that board has full responsibility for overall banking activities, making strategies, governance framework and corporate culture. Proper code of ethics must be followed; proper communication flow must prevail within the members of banks. Board members should be qualified and should also take the responsibility for maintain effective corporate governance in the banks. The board should define appropriate governance structures and practices for its own work, and put in place the means for such practices to be followed and periodically reviewed for effectiveness. Senior management should carry every activity of the banks under the guidelines and supervision of board members and each of the board members, senior management should take proper responsibility ensuring there is a clear governance framework appropriate to the structure of the business.

Banks should have independent risk management function where every possible risk are identified, monitored and managed properly with sufficient resources and access to boards. Proper communication must be flowed about the risk across the organization. The bank's board of directors is responsible for overseeing the management of the bank's compliance risk. The board should approve the bank's compliance approach and policies, including the establishment of a permanent compliance function. Internal audit helps in promoting effective governance in the banks. It should be clear, accountable and have sufficient standings, skills, resources and authority within banks. Compensation systems form a key component of the governance and incentive structure through which the board and senior management promote good performance, convey acceptable risk taking behavior and reinforce the bank's operating and risk culture. The governance of the bank should be adequately transparent to its shareholders, depositors, other relevant stakeholders and market participants. Supervisors should provide guidance for and supervise corporate governance at banks, including through comprehensive evaluations and regular interaction with boards and senior management (NRB, 2014).

Organization for Economic Cooperation and Development (OECD - 1999): In 1999 OECD was incorporated as basic principles of corporate governance which includes protection of shareholder's rights entailing that the shareholders rights must be maintained all times ensuring continuous flow of needed capital. Equitable treatment should be provided to shareholders, all the investors may be minor and major should be given equitable preference. Clear, consistent accurate, timely information must be disclosed by corporations during its good time or bad time. Board members should be selected diligently and board elections should be free from political interference. Board members should exercise their duties and responsibilities persistently. OECD principles, amended in 2015 ensures the basis for an effective corporate governance framework -- through legal monitoring procedures, clear division of responsibilities and the boards implied power and integrity to achieve their duties. Shareholders bear the right to elect or even remove the boards' members, to be informed about urgent decisions, and inquire the board. Transparency on issues regarding finance, ownership, performance and governance of the company are to be made. The responsibilities of the board: observing the strategies, plans, actions, monitoring the corporation's governance practice, besides ensuring new changes as needed. 


\section{Best practices of corporate governance around the world}

Housing Development and Finance Corporation Bank (HDFC - 2018): Established in India in 1994 with the slogan "we understand your world", HDFC is the largest banking and financial service provider in India with highest market capitalization having head-quarter in Mumbai and also present in Hong Kong, Bahrain and Dubai. The bank relies on the core value of operational excellence, product leadership, customer focus and sustainability which can be linked with the pillars of corporate governance. Corporate policy of bank is built on Regulatory requirements that means bank make sure that every legal requirements are fulfilled properly in written and spirit. The bank is transparent in its operation and other activities to its internal and external stakeholders. Similarly, bank has strong code of ethics that are to be followed and it tries to provide maximum value to its shareholders providing them with responsibility to make the performance of bank more effective. Likewise, bank is involved in various CSR activities and also won best CSR award at the business responsibility award 2007.

CSR committee holds meeting at the interval of every six months to make update of their ongoing progress and further strategies. However, bank mainly focuses on environmental and societal aspects dedicated in e-transaction, energy conservation, renewable energy, financial stability of rural people. Bank has also started sustainable livelihood initiatives in order to empower rural women's and upgrade their lives and lifestyles by providing them trainings. Education crisis support is provided to needy and diligent children where scholarship of Rs. 10,000 annually is provided up to school level and Rs. 25000 is provided annually up to university level. Bank comprises of strong and independent board members having six independent directors, five non-independent directors, three exceptional directors and all others non-executive directors. HDFC has code of ethics that is levied and to be followed from top level employees to lower level employees. Copy of code of ethics is provided to anyone without charge upon request. The code comprise of various ethical conducts, conflict of interest, confidentiality of information, disclosure of information, violation of code and so on. Bank has also adopted whistleblower policy for receiving, retaining and treating complaints received by anonymous employees.

For the purpose of risk management bank's key aspect is to identify measure, monitor and control risks. There is line of reporting in every function which facilitates reporting, monitoring risks, and various management information systems are also used in order to manage and identify the risks. Bank constitute of various committees like customer service committee, credit approval committee, Investor grievance committee and so on. It makes the work of each committee easier and helps to take best decision and make best strategies.

Federation of International Football Associations (FIFA) Executive Committee is the author of both, the ethical code of conduct and the disciplinary code. These codes specify the most proper values and principles to be followed in acting and behaving within FIFA and with all related partners. These codes are applied to all members of FIFA at all levels (FIFA, 2012). FIFA has set 11 main principles in its code of conduct. All FIFA members are obliged to act ethically with full integrity behaving with respect to one's dignity, privacy and personal rights. There should be no verbal or physical harassment or discrimination. All actions and 
decisions should be practiced in respect to rules and conventions. FIFA should have compliance with rules, laws, and regulations, respect and compliance to all internal rules and laws. Conflicts of interests should be avoided by prioritizing the organization's goals. Transparency should be made by constant seeking to fair play and complying with outlined laws and regulations. FIFA is also involved in social and environmental responsibility, participating toward positive social change and minimizing the harm or negative consequences of FIFA's activities to the environment. It has also been initiating programs to fight against drugs and doping and zero tolerance of bribery and corruption with total prohibition of intervention or manipulation of the results of football matches.

\section{Relationship between corporate governance, CSR and social entrepre- neurship}

Jamali, Saffieddine and Rabbath (2008) have stated CG and CSR as the calls on companies to assume their performance and moral responsibilities toward stakeholders. This act of accountability is crucial for a business to gain and retain the trust of its financial investors and other stakeholders (Page, 2005). Both concepts thus draw vigor from the same sources, namely transparency, accountability, and honesty (Van den Berghe \& Louche, 2005). Marsiglia and Falautano (2005) have suggested that good CG and CSR initiatives are gradually advancing from a philanthropic variant of corporate capitalism to authentic strategies intended to regain the trust of clients and society at large. While CG implies being held accountable for, CSR means taking account of and both mechanisms are increasingly used by firms to regulate their operations (Beltratti, 2005; Marsiglia \& Falautano, 2005). Windsor

Figure 1: CSR embedded in CG

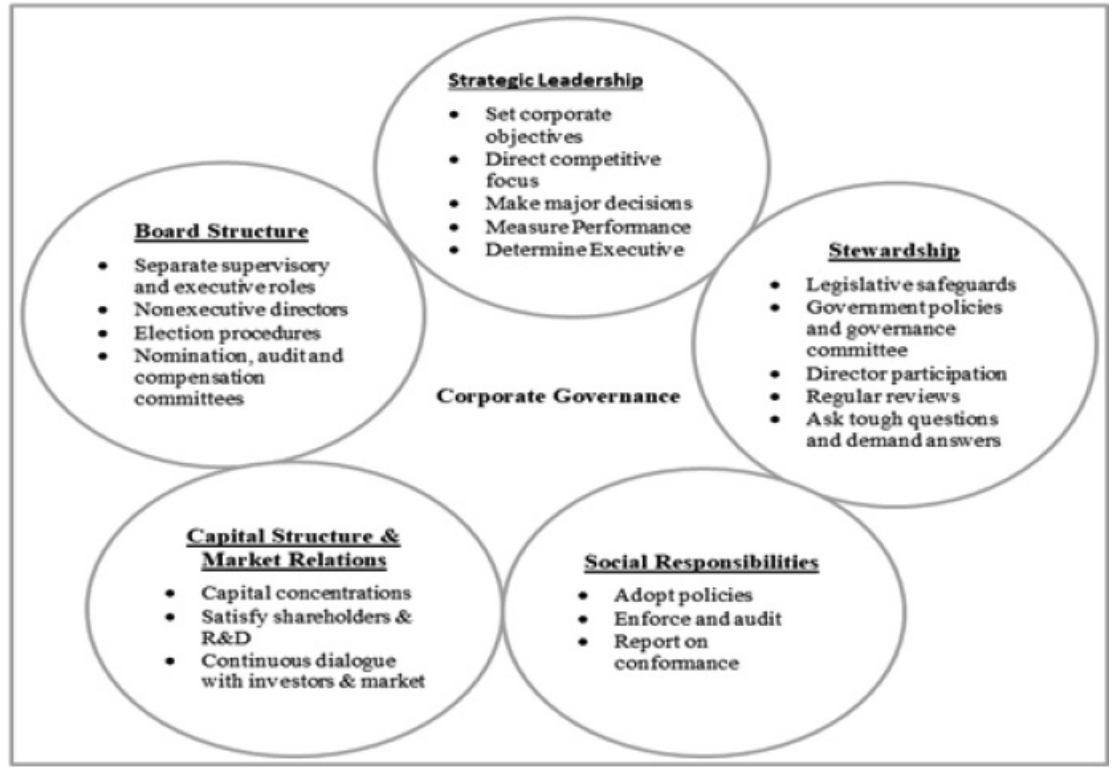

Source: Ho (2005). Corporate governance and corporate competitiveness: an international analysis. 
and Preston (1988) have argued that within the framework of legitimacy theory, CG and CSR are related ideas defining the interaction between an organization and its internal and external sociopolitical environment, with both increasingly considered as fundamental prerequisites for sustainable growth within a globalizing business environment (Van den Berghe \& Louche, 2005). Both disciplines are also perceived to confer important long-lasting benefits and to ensure the endurance of the business.

Above figure 1 shows corporate governance can be attained through embedding them in various CSR activities by organizations. Corporate governance can be achieved by organization through maintaining good relationship with customers, suppliers and so on. Various policies formulated for social responsibility must be carried out properly enforcing them effectively and conforming them for better output. When organization operates in society in must be accountable to society it is operating in. It helps in building good customer base, image, and reputation of organization itself improving on overall organization structure which would help in ensuring good corporate governance to certain extent.

Through proper execution of CSR activities other organizational activities also gets promoted in the market. Likewise, well-managed board structure, well selected directors are necessary for proper planning, execution of the plans and policies of the organization. Also, they can plan or designed good and relevant CSR activities through which leadership trait can be attained in an organization building strong capital structure and market relation which can be turned into strength of organization. Similarly, coping with policies, plans formulated by government on CSR activities would safeguard organization from getting into government penalties. CSR activities also help in R\&D activities of an organization. In nutshell, properly executed CSR activities help in satisfying the stakeholders.

Schwab and Sala-i-Martin (2016) have depicted social enterprises are inclined towards solving the social issues and problems through employing scalable, self-sustainable and innovative business models. They must balance financial responsibilities and social impact and must coordinate among multiple stakeholder groups, including investors, employees, regulators, clients and beneficiaries. A carefully selected, well-designed and well-managed board will help the social enterprises to reach its goals. It further helps to ensure the vision and legacy by empowering boards and carefully selected individuals to guide the enterprise. This ensures the organization's vision succeeds beyond the efforts of the founder or management team. It helps in providing credibility to external stakeholders: Investors, contractors and customers may trust the organization more if it has well-regarded board members. The legal, financial structure of the enterprise must be formulated and implemented well complying with regulatory frameworks stated for enterprises.

\section{Issues and challenges facing CSR and social entrepreneurship promo- tion in Nepal}

According to World Bank, Good governance involves sound public sector management, efficiency and economic progress, transparency, legitimacy, justice and respect for human rights and law. Various issues and challenges being faced by Nepalese corporate sector in imple- 
mentation of CSR and SEP are: corruption, Nepal has been listed as one of the most corrupt nations. According to Transparency International Nepal ranks 116th position out of 177 at the list of corrupt nations. Similarly, apart from corruption, nepotism, favoritism is another issue in Nepalese corporate context. Handing over better jobs to their close friends and relatives is the major issue of corporate hoses these days. Working together with various ethnic groups and culture for a common goal is another hurdle.

In such case, implementing of any program, policy in organization is challenging tasks. Organization has to face various resistances while trying to implement any new initiatives in corporate sectors due to various reasons. Some of the issues and challenges can be discussed as: The relevance of social entrepreneurship very much depends on the economic conditions in the respective countries. However, the challenges faced by Nepalese corporate sector for promoting social entrepreneurship are:

\begin{tabular}{|l|l|}
\hline Transferring the business ideologies & Encouragement from the government \\
\hline Donation programs & Maintenance of the product qualities \\
\hline Efficient allocation of human resources & Competitive scenario \\
\hline Time management for entrepreneurial focus & Introduction of the technologies \\
\hline
\end{tabular}

One of the major issue and challenges which has obstructed the development of entrepreneurship in Nepalese society is the culture and mind-set of Nepalese. It is still believed by Nepalese that getting into the established job is accessing to secured lifestyle. So, people rather look for jobs rather that thinking of starting of their own business. They believe that starting of something new would cost high, requires greater effort, is time consuming and is risky. People rather wants to remain in safer side which have narrowed down their creativity, suppressed innovative ideas and stopped themselves for doing what they actually want to do. Another reason is family and peer pressure that always hold them back stopping them to enter into new business thinking them riskier. Nepal being developing nation and most of its citizens are from middle class family one of the major challenges for entrepreneurial development in Nepal is limited financial resources. Tax and legal procedures can be one of other issues for entrepreneurial development in our country. As there is no proper intellectual property right policy starters are always afraid that their products or service could be easily copied and brought in the market. They hold the fear that their products or service could be cannibalized in the market shortly.

Transformation of Nepalese corporate sectors towards engagement in the corporate social responsibility has been drastically changing and has been compulsory part of the business. This phenomenon has resulted to following issues and challenges for Nepalese corporate sector for enhancing corporate social responsibility activities. 


\begin{tabular}{|l|l|}
\hline Support from nations government & Societal conception towards CSR \\
\hline Regime transitions and regulations & Differing customers' needs \\
\hline Corporate management policies for CSR & Investors' concerns for CSR activities \\
\hline Fund management & Awareness among the management \\
\hline
\end{tabular}

Major challenge for implementing CSR is fund management. Most of the businesses in Nepal are small-scale and not every organization is in the state that they can allocate fund for CSR. Proper rules and policies are not formulated by government for CSR activities except for financial institutions which makes CSR activities voluntary for organizations so they contribute to it as per their wish. There is lack of awareness among management about the importance of CSR so they don't pay much attention on these sectors. Society is also being dependent on corporate houses stating they should conduct development activities in society as CSR which is difficult for corporations to meet needs of individuals of society.

\section{Prevailing state of compliance of corporate governance, CSR and social entrepreneurship in Nepal}

Corporate governance ( $C G$ ) refers to the set of organizational rules, policies, practices and defined processes that coordinates and directs the functioning of the organization. The proper understanding and recognition of the interests of the stakeholders of the organization are balanced through corporate governance. The stakeholders consist of the shareholders, employees, customers, suppliers, government and the community of the nation.

Nepal Rastra Bank (NRB) regulates the activities of the Nepalese corporate sectors and also regulates the practices of the Nepalese corporate sectors and their corporate governance practices. Government of Nepal and NRB has continued to formulate the principles and policies for the safeguard of the corporate activities with all of the corporate sectors functioning within the country. The development of the corporate governance practice evolved progressively after 2006 in the context of Nepal and various legal and institutionalized frameworks have been developed to regulate the corporate governance activities where various rules and laws have been developed to regulate good governance practices and incorporated in Companies Act 2006, BAFIA 2006 and Securities Act 2006.

The elected VDC members, Municipality members or Metropolitan members governs the activities of the local level administration according to the constitution of the Nepal.The negative side of the governance is that the local level elections are away and not conducted for around 15 years. This has resulted to inefficient contorlling and survilliance of the local level for the practices of the corporate governance activities at the local and community.Corruption in the government, private and other major public sectors has been the major problem of Nepal. The transparency are highly low among the Nepalese corporate sectors and especially the issues of the corruption are huge in the government organizations. The customers and the corrupt officers both are seen responsibe for the growing corruption which has enhances corruption as it has become a two way process between the giver and the taker. 
Asian Development Bank (2018) has revealed that government of Nepal has started focusing on strengthing performance through accountability, transparency, environmental prospects leading to save cost and time. Employee friendly softaware are being installed in organizations for increasing efficiency and ouput. Various corruption control tools were introduced and gender issues were addressed encouraging and promoting women empowerment in local governance. After the federalism funds are transfered directly to local treasury from central treasury for effective dissemination of funds to required sector. Government has started working basing upon pillars of corporate governance.

The increasing favourability, nepotism, and taking responsibilities fulfillment as a secondary priority have emerged as the institutional prolem in the Nepalese corporate sectors. Viewing the social and the cultural aspects of the Nepal, the decision making process are relatively taking by the head, which have lacked the participation of the employees, customers and other relative stakeholders of the organization in the decision making process. The organizations stalemate and deadlocks have resulted stakeholders to be pessimistic aboutfor the upliftment of the stakehohders, community and the organization. The process of allocating the jobs to the relatives and family members rather than the deserved personnals or the candidates have benn the major problem of the Nepalese corporate sectors which obsiously effects the social and economoic performance of the corporate sectors. The problem of transparency, responsiveness and accountability thus have been the major problems in the Nepalese sector.

Nepalese companies have not realized the actual meaning of CSR, neither proper CSR laws are formulated in the country (Shah, 2012). Still employees of both public and private companies in Nepal lacks the awareness about CSR and its implication that CSR if implied properly can bring positive attitude towards the company (Adhikari, 2012). Adhikari et al. (2016) have discussed that awareness about the importance of CSR in Nepalese companies is growing and the reason behind this is emergence of managers, employees of new generation in the organization who have knowledge on CSR and its importance to the organization. Corporate Social Responsibility (CSR) is the continuing commitment by businesses to behave ethically and contribute to economic development while improving the quality of life of society at large. It is about enterprises deciding to go beyond minimum legal requirements and obligations stemming from collective agreements in order to address societal needs. There are two ways of CSR partnerships: financial partnerships in which money flows directly, and non-financial partnerships in which technical inputs or products are distributed. By showing their corporate social responsibility, private companies in collaboration with development actors (such as NGOs) can contribute to making the water and sanitation sector more sustainable.

Industrial Enterprise Act [IEA] and Nepal Rastra Bank's regulations have made the CSR activities mandatory for the Nepalese corporate sectors especially for the banking, industries and the financial sectors. Industrial Enterprise Act 2016, Chapter 9, Section 48[1] has made the CSR activities mandatory for the industries and other corporate sectors on the basis of fixed capital investment and annual turnover and explains Small scale industries with fixed capital investment of less than NPR 100,000,000 and annual turnover of NPR 
150,000,000 should contribute for the CSR activities. Similarly medium scale industries with fixed capital investment of NPR 100,000,000-250,000,000 should allocate the fund for the CSR activities and do not concern with the annual turnover. Also the large scale industries with fixed capital investment more than 250,000,000 are made compulsion for the CSR activities. The industries and companies will be fined 0.75 percent of the annual revenue if found not involved in the CSR activities. Also according to the circular for bank and financial institutions issued by the Nepal Rastra Bank, the banks and financial institutions should deposit the CSR fund. The deposits are targeted to at least one percent of the net profit and for not fulfilling the CSR activities the fine and imprison are made according to Nepal Rastra Bank Act 2002. Some of the contributions of Nepalese corporate sector for the CSR activities are:

Nepal Telecom: Nepal Telecom has been engaging themselves in various CSR activities. Some of the CSR activities they have been engaged are they had worked for welfare of the earthquake victims. The company invested huge amount for free mobile call services amounting to Rs 1.46 billion immediately after the disaster. Major target of the organization is to reach to the remote sector of the country via the help of the internet services. Also, Nepal Telecom helped victims of rural areas for promoting health posts and schools via WiMAX connectivity (Nepal Telecom, 2017).

As per the information generated from Nepal Telecom (2017) Bagmati River Clean-Up campaign is also one of the major social welfare activities of Nepal Telecom focusing on the conservation of the environment. The SMS services have also been introduced by the NT to increase the participation of the general public in the cleaning activities.

NMB Bank: NMB Bank, in association with Kathmandu Metropolitan City Office, has been working for the preservation of the cultural heritage of the country. Bank places donation box for the purpose of fund raising during week-long event. Bank has worked and maintained Goraknath Temple at Thapathali and Luchu Bhuju Ajima Temple at Ganabahal, Kathmandu from the funds collected through the process of Heritage Walk campaign (NMB Bank, 2019), which has helped in preservance of monuments of the nation and helped in saving culture of the country.

SNPL Khelparyatan: Surya Nepal (2019) has introduced that SNPL Khelparyatan is an initiative of Surya Nepal under their CSR activity. This CSR activity primarily focuses on promoting sports tourism. SNPL has been continuously sponsoring golf tournaments for the development and the promotion of the professional golf in Nepal. The long running SPNL Golf Tour has worked as one of the major focus for golf tournaments in the country.

MIT GSL Program (Ncell): Ncell in 2018 collaborated with Massachusetts Institution of Technology (MIT), USA, one of the world's prestigious university and Kathmandu University (KU), Nepal to implement MIT Global Startup Labs (GSL) in Nepal to empower technology entrepreneurs and help cultivate the startup ecosystem of the country. This pioneering program was initiated by Ncell as a part of a company's CSR initiative and in line with its vision to help nurture technopreneuship sprit among young talent through innovation. For the first year, the program targeted students and alumni of KU. 35 students and alumni of $\mathrm{KU}$ who aspired to make a change through innovation digital business ideas were selected 
for MIT GSL Nepal program, an intensive 7 weeks innovation boot camp, where participant develop start up project for ideation stage to execution of technology startup under the mentorship by MIT instructors (Ncell, 2019).

Mega Bank: Since the inception of the institution, Mega Bank Nepal Limited has been dedicated towards contributing to the society and maintaining a strong relationship between the institution and the community at large. In order to do so the Bank has contributed in various programs, including education \& health initiatives, various NGO programs and sporting activities, as well as in supporting the less privileged sections of our society (Mega Bank, 2019). This has helped bank to stay stronger with good relation with society they are operating in and their customers.

In context of Nepalese corporate sectors, government provides subsidies if corporate sectors are engaged in social entrepreneurial promotion related to export of the products and services. Industries are targeted to promote by the government, and for the entrepreneurial organizations that are established in least, undeveloped and under-developed parts of the country. Government has allocated such promotion and arrangement of subsidies to enhance the investment of least developed areas and growth of prioritized industries within the countries. Compulsion for corporate sectors to promote social entrepreneurship is not mandatory but some of the corporate sectors target process of social entrepreneurship according to their rules, policies and objectives. Some of the social entrepreneurial sectors doing wonderful job in Nepalese society can be listed as below:

Three Sisters: Three sisters have been working for providing the training for the empowerment of women and involve various training programs for women. Female trekking guide training can be one of the major activities for entrepreneurial development and it includes courses on leadership, conversational English, tourism, ecotourism, history and geography, environmental responsibility, health and hygiene awareness, culture and religion, flora and fauna and first aid, Altitude Mountain Sickness with emergency procedures. It has worked as the forum for entrepreneurial development of the women in tourism sector of the Nepal. These activities have helped women for engaging in the occupation related to forming their own tourists guide, tourism industry and others (3 Sisters Adventure Trekking, 2019).

Global IME: Global IME Bank (2019) has started providing financial help for graduates taking their graduation certificates as collateral. The amount of around NRs. 1,500,000 is provided by the global bank for the growth and development of entrepreneurial activities in Nepal which has also taken an initiative to decrease brain drain and helped to foster entrepreneurial activities in Nepal.

Maya Universe: Maya Universe provides free education for underprivileged children in rural parts of Nepal parents simply spend two days a month in organic farming and animal husbandry in exchange. Revenues from products and goods sold are then used to support the program's educational efforts. Nepal with its growing number of social enterprises is a global leader in creating sustainable models for solving complex social problems with local human and natural resources. In fact, the country recently hosted its first international conference on social entrepreneurship attended by social enterprise leaders from the around the world (Maya Universe, 2019). 
The Village Café: Established in 2009, The Village Cafe trains female home-based workers who have social or economic disadvantages. Their training varies from agricultural work to being professional cooks. The cafe sources local produce and ingredients from women in Nepal and also trains these women to have a quality product. Women also undergo training to work in the restaurant where these once home cooks become professionals by learning about hygiene and western standards of cooking focusing specially on traditional Newari food. With the exception of being in a locals home, the place have best Nepali food and the prices are completely affordable. With serving people with delicacies the place is trying to save the culture and tradition as well (The Village Café, 2019).

\section{Outcomes of private sector CSR and social entrepreneurship contribution} Effective CG compliance in corporate sector would help in effective system implementation, proper follow up of rules and regulations. It would further help in increasing effectiveness and motivating employees for better organizational performance which could result in improvement in overall organizational performance. Similarly, it helps in improving transparency and accountability in firm's performance aiding to effective branding of corporate identity. It also helps in improving public relation and transformation of global competitiveness of local market, resources and industries.

Although there are various financial aspects related to the execution and implementation of corporate social responsibilities and social entrepreneurship also seems emerging in our country, Nepal. Business works for the promotion of such activities for the purpose of promotion and establishment of brand image among customers and other related stakeholders. Corporate sectors view such societal promotion activities and entrepreneurial promotion for the purpose of wealth maximization of organization as the outcome of their contribution.

Corporate social responsibilities are voluntary activities that are undertaken by corporate sectors for the promotion and up gradation of social life of the people. CSR activities are also made mandatory by the government of Nepal. Thus such activities are carried out by the organization for generation of certain outcomes. Active participation of corporate sector expects organization to ascertain government support and minimize regulatory actions that are charged by nation's policies and rules. Corporate sector also expects advertisement and promotion of business that enhances its brand image and reputation through the process of corporate social responsibility carried out by the organization. Promotion of the organization ultimately enhances sales and economic benefits of the organization and also assures product safety and reduces liability of the organization.

Social entrepreneurship aims to identify social problems and work for its commercial success. Enhancement of creative and innovative ideas is focused following nonprofit concept for execution of societal activities. Considerations of societal issues are identified with the formation of alliances for successful implementation of social and commercial approaches to minimize social problems. Moreover the major role of social entrepreneurial promotion is to minimize and share the role of government for promoting social and economic life of people. 
Social enterprises major outcome is to generate employment opportunities and provide training for the job creation for the personals if the business and for large segment of people of the society. Social enterprises identify societal problems and focuses to develop new product and services for the up gradation of social and economic condition of people. Services may involve outcomes related to health, promotion of education, reduction of illegal activities and others. Social enterprise works for the promotion of brand and image of the organization. Customer's preference and attitude must change with the societal focus that has been promoted and carried out by the organization.

\section{Methodology of works}

This paper has been based on the qualitative analysis of relevant issues diagnosed and analyzed by the help of exploratory research design. Formal and informal discussions were held with the professionals representing related fields of specialization for the purpose of information generation and evaluation. Similarly, expert advices were solicited for receiving needful guidance of the present work.

As a desk review based paper, the work as a whole, has been based on published journal articles at national and international level. In addition, various policy reviews were accomplished to get acquainted with the prevailing rules, regulations and governing guidelines pertaining to corporate governance, CSR and social entrepreneurship initiatives.

Significant variety of information was gathered from different company profiles and websites that were relevant to explore institutional standing on CSR and social entrepreneurial activities. This study comprises all the information from secondary sources of data collection and does not include any information from primary sources.

Thus, it can be claimed as a critical review based paper which has been developed on a fully qualitative paradigm of research.

\section{Key findings of the study}

Corporate social responsibility (CSR) is about building a socially responsible business striving for social change along the line of seeking profits. The overall CSR penetration in Nepal is quite low with many corporations not familiar with its broad concept. Majority of the CSR activities in Nepal are socially driven projects that help to empower marginalized communities. CSR is made mandatory for industries, banks and financial institutions (BFIs), as governed by Industrial Enterprise Act (IEA) and Nepal Rastra Bank's circulars respectively. Similarly, social enterprises are emerging in context of Nepal and government is also showing interest in this sector. Social entrepreneurship is on the way of gaining footage over the last few years. Some of the key findings generated from the study can be listed as below:

a. CSR and social entrepreneurship orientation have been emerging in Nepal more recently.

b. CSR activities are seen practiced by the Nepalese banks and financial institutions but other corporate sector still lacks the practice to a full potential and coverage. 
c. Awareness about social entrepreneurship, its importance and contribution in country's economy is required, especially in rural parts of the nation and to the corporations as well.

d. The government is also paying more attention towards the promotion of CSR and social entrepreneurship initiatives by providing subsidies, lower tax rates, and lower interest rates for them who are taking loan for operating social enterprises.

e. Constitution of Nepal and other legal premises have included CSR activities as organization's voluntary initiatives extended for the welfare of customers, employees, general public environment and many other stakeholders.

f. Prevalence of political and policy level stability and control over corruption will help new entrepreneur to enter and existing ones to operate smoothly.

\section{Conclusions}

Based on major finding of this paper, it may be concluded that participation of corporate sector in CSR and social entrepreneurial development shares and minimizes responsibilities of the government or public sector. Also the culture and follow-up of the practices can be established as set of policies and practices in organization. These activities ultimately act as the medium for effective communication and promotion of corporate sector, ultimately resulting with their corporate image and social branding. Enhancement of social life can be achieved by executing innovative and creative ideas of corporate governance. Ultimate aim of organizations involved in the process of CSR and social entrepreneurial development is to establish positive relationship with the community, society and to government for the promotion of their business and sustainable development.

In context of Nepal, development and promotion of CSR and social entrepreneurship initiatives have been booming. However, initiation must be taken from the side of government, corporate houses and entrepreneurs for strengthening each sector. Government should formulate strict rules and regulations and corporations should take their responsibility for the growth, development and promotion of CSR and social entrepreneurship initiatives as the means of inclusive development of the country. Also, the general public need to be aware about social enterprise system and its significance in national development.

\section{Strategic recommendations for policy implications}

The evidences observed during the period of this study reveal that effective practice of corporate governance still seems lacking in the Nepalese corporate sector. Though CSR seems to be emerging these days, social entrepreneurship is still in the infancy stage of development. If the governments along with corporate houses join hands together to implement and follow corporate governance system practices effectively, outputs beyond expectation can be attained. 
National rules, regulations and policies of corporate sector need be well-governed and complied with. These are a few suggestions in this respect:

a. In coordination with local and provincial governments, the federal government should formulate strict legal frameworks and system standards making it a mandatory proposition to focus on CSR and social entrepreneurial development initiatives for all type of business institutions.

b. Local and provincial governments must provide incentives and encouragement for the corporate sector operating in their areas and boost their existing activities in order to motivate them as well as others to come up with innovative ideas.

c. Local government should make collaboration with corporate sector to enhance the CSR activities so that both community and organization gets benefitted.

d. Federal and provincial governments should initiate the growth and development of the social entrepreneurship and provide financial benefits like subsidies, loan at lower interest rates for the corporate sector promoting with entrepreneurial development instruments and activities.

e. Local and provincial governments should consider tax rebates in order to promote entrepreneurial activities in remote areas of the country for the upliftment of lives of the people in rural areas and to aid in the process of development of these areas.

Established companies and large scale industries seem to have adopted a system approach to corporate social responsibility but social entrepreneurship is still in developing phase. It can be listed in numbers as there are very few corporate entities focusing on this aspect.

a. Consistent execution of the CSR programs should be made by concerned authorities for the purpose of comparing outcomes and recognition of the practices of CSR activities performed by the corporate sectors.

b. Establishing the organizational culture, policies and practices for promoting the CSR within an organization so that CSR gets continuity in that organization and serves its purpose rather than just meeting the required obligations formulated by government.

c. Changes in the concept of management of the organization for characterizing and understanding the changing scenario of predicting the societal promotion and CSR activities and making them aware that CSR is more than just promotional activity.

d. Organizational policies and strategies should be enhanced at local and provincial level to promote social entrepreneurial activities bringing creative and innovative ideas from employees.

e. Funding and financial allocation should be enhanced within the organization for the promotion of social entrepreneurship so that people get motivated and feel secure in investing into new business. 


\section{References}

Adhikari, D. R. (2012). Status of corporate social responsibility in selected Nepalese companies. Corporate Governance: The International Journal of Business in Society, 12(5), 642-655. Available at: https:// www.emeraldinsight.com/doi/abs/10.1108/14720701211275578?journalCode=cg. Retrieved on: January 15, 2019.

Adhikari, D. R., Gautam, D. K., \& Chaudhari, M. K. (2016). Corporate social responsibility domains and related activities in Nepalese companies. International Journal of Law and Management, 58(6), 673-684. Available at: https://sci-hub.tw/10.1108/ijlma-08-2015-0044. Retrieved on: April 28, 2019.

Ajina, A., Lakhal, F. \& Sougné, D. (2015). Institutional investors, information asymmetry and stock market liquidity in France. International Journal of Managerial Finance, 11(1), 44-59. Available at: https://sci-hub.tw/10.1108/ijmf-o8-2013-0086. Retrieved on: May 3, 2019.

Al-Azzam, Z. F., Al-Mohameed, H., \& Al-Qura'an, A. (2015). How the corporate governance affects organizational strategy: lessons from Jordan environment. Journal of Business and Management (IOSRJBM) Vol, 17. Available at: https://papers.ssrn.com/sol3/papers.cfm?abstract_id=2710595. Retrieved on: May 3, 2019.

Ashley, P. A. (2012). Social responsibility in a context of change: from corporate and organizational, to networks, markets and territories. Global Values in a Social World, 121-15o. Available at: https:// www.researchgate.net/publication/257542333_Corporate_Social_Responsibility_in_Global_Value_Chains_Where_Are_We_Now_and_Where_Are_We_Going. Retrieved on: April 28, 2019.

Asian Development Bank [ADB] (2018). Private sector assessment (summary). Country Partnership Strategy: Nepal. Available at: https://www.adb.org/sites/default/files/linked-documents/cpsnep-2013-2017-psa-summary.pdf. Retrieved on: May 11, 2019.

Baker, M. (2004). Corporate social responsibility: what does it mean? Available at: http://www. mallenbaker.net/csr/CSRfiles/definition.html>. Retrieved on: May 3, 2019.

Bielefeld, W. (2009). Issues in social enterprise and social entrepreneurship. Journal of Public Affairs Education, 15(1), 69-86. Available at: https://www.tandfonline.com/doi/abs/10.1080/15236803 .2009.12001544. Retrieved on: May 1, 2019.

Casson, J. (2013). A review of the ethical aspects of corporate governance regulation and guidance in the EU. Occasional Paper, 8, 1-44. Available at: https://www.zdruzenje-ns.si/db/doc/upl/ibe_occasional_paper_8_a_review_of_the_ethical_aspects_of_corporate_gove_.pdf. Retrieved on: May 8, 2019.

Chapagain, B. R. (2010). Corporate social responsibility: evidence from Nepalese financial service and manufacturing sectors. Economic Journal of Development Issues, 9-20. Available at: https://www. nepjol.info/index.php/EJDI/article/view/6103. Retrieved on: January 16, 2019.

Cornett, M. M., Marcus, A. J., \& Tehranian, H. (2008). Corporate governance and pay-for-performance: the impact of earnings management. Journal of financial economics, 87(2), 357-373. Available at: https://www.sciencedirect.com/science/article/pii/So304405X07001651. Retrieved on: May 9, 2019.

Dees, J. G. (2017). 1 The Meaning of Social Entrepreneurship. Case Studies in Social Entrepreneurship and Sustainability, 34-42. Routledge. Available at: https://www.taylorfrancis.com/ books/e/978135127856o/chapters/10.4324/9781351278560-14. Retrieved on: May 10, 2019.

FIFA Code of conduct (2012). FIFA homepage. [Online], Available at: http://www.fifa.com/mm/docu- 
ment/. Retrieved on: May 8, 2019.

García-Marco, T., \& Robles-Fernández, M. D. (2008). Risk-taking behavior and ownership in the banking industry: the Spanish evidence. Journal of Economics and Business, 6o(4), 332-354. Available at: https://www.sciencedirect.com/science/article/pii/So148619507000434. Retrieved on: May 3, 2019.

Gilberthorpe, E., \& Banks, G. (2012). Development on whose terms? CSR discourse and social realities in Papua New Guinea's extractive industries sector. Resources Policy, 185-193. Available at: https://www.researchgate.net/publication/241091048_Development_on_whose_terms_ CSR_discourse_and_social_realities_in_Papua_New_Guinea's_extractive_industries_sector. https://www.researchgate.net/publication/298075046. Retrieved on: January 20, 2019.

Global IME. (2019). Loan and advances: global small business loan. Kathmandu: Global IME Bank Limited. Available at: http://globalimebank.com/global-small-business-loan.html. Retrieved on: January 20, 2019.

Hdfc Bank Limited. (2019). About us: corporate governance. Mumbai: HDFC Bank Limited. Available at: https://www.hdfcbank.com/aboutus/cg/Corporate_Governance.htm. Retrieved on: May 1, 2019.

Ho, C. K. (2005). Corporate governance and corporate competitiveness: an international analysis. Corporate Governance: An International Review, 13(2), 211-253. Available at: https://onlinelibrary.wiley.com/doi/abs/10.1111/j.1467-8683.2005.00419.x. Retrieved on: May 17, 2019.

Ismail, M. (2009). Corporate social responsibility and its role in community development: an international perspective. Journal of International Social Research, 2(9). Available at: https://www. researchgate.net/profile/maimunah_ismail/publication/40426284_corporate_social_responsibility_and_its_role_in_community_development_an_international_perspective/ links/o046352033f776fbaooooooo/corporate-social-responsibility-and-its-role-in-community-development-an-international-perspective.pdf. Retrieved on: May 17, 2019.

Jalilvand, M. R., Samiei, N., Dini, B., \& Manzari, P. Y. (2012). Examining the structural relationships of electronic word of mouth, destination image, tourist attitude toward destination and travel intention: an integrated approach. Journal of Destination Marketing \& Management, 1(1-2), 134143. Available at: https://www.sciencedirect.com/science/article/pii/S2212571X12000157. Retrieved on: April 25, 2019.

Jamali, D., Safieddine, A. M., \& Rabbath, M. (2008). Corporate governance and corporate social responsibility synergies and interrelationships. Corporate Governance: An International Review, 16(5), 443-459. Available at: https://www.academia.edu/4636268/Corporate_Governance_ and_Corporate_Social_Responsibility_Synergies_and_Interrelationships. Retrieved on: May 16, 2019. Retrieved on: July 22, 2019.

Kandel, L. R. (2018). Corporate social responsibility in Nepalese commercial banks with reference to Bank of Kathmandu Limited. NCC Journal, 3(1), 90-99. Available at: https://www.nepjol.info/index.php/NCCJ/article/view/20251. Retrieved on: May 3, 2019.

Leadbeater, C. (1997). The rise of the social entrepreneur, (No. 25). Demos. https://books.google.com.np/books?hl=en\&lr=\&id=AevsF1s6oLUC\&oi=fnd\&pg=PT6\&dq=Leadbeat er,+C.+(1997).+The+rise+of+the+social+entrepreneur+(No.+25).+Demos.+\&ots=ZjCg3d1Jt$\mathrm{D} \&$ sig=aBZEr2uMvgigUf6z4muF5D6PLBA\&redir_esc $=\mathrm{y} \# \mathrm{v}=$ onepage\&q\&f=false. Retrieved on: May 8, 2019.

Manfredi, F. (2005). Social responsibility in the concept of the social enterprise as a cognitive system. 
International Journal of Public Administration, 28, 9-10 \& 835-848. Available at: https://www.tandfonline.com/doi/abs/10.1081/PAD-200067371. Retrieved on: May 6, 2019.

Marsiglia, E., \& Falautano, I. (2005). Corporate social responsibility and sustainability challenges for a bancassurance company. The Geneva Papers on Risk and Insurance-Issues and Practice, 30(3), 485497. Available at: https://link.springer.com/article/10.1057/palgrave.gpp.2510040. Retrieved on: May 8, 2019.

Matten, A., \& Crane, D. (2005). Corporate citizenship: toward an extended theoretical conceptualization. Academy of Management Review, 3o(1), 166-179. Available at: https://journals.aom.org/doi/ abs/10.5465/AMR.2005.15281448. Retrieved on: April 20, 2019.

Maya Universe Academy. (2019). Social enterprise. Tanahun: Author. Available at: https://mayauniverseacademy.org/about/about-maya/. Retrieved on: May 8, 2019.

Mega Bank Limited. (2019). Quick links: corporate social responsibility. Kathmandu: Mega Bank Limited. Available at: https://www.megabanknepal.com/page/corporate-social-responsibility. Retrieved on: May 8, 2019.

Mulgan, G., \& Landry, C. (1995). The other invisible hand: remaking charity for the 21st century. Demos, 15. Available at: https://books.google.com.np/books?hl=en\&lr=\&id=1ccdv5addeuc\&oi=fnd\&p$\mathrm{g}=\mathrm{pt}$ \&dq=the+other+invisible+hand+remaking+charity+for+the+21st+century\&ots=5lglksgzkk\&sig=vmnhkessn4mwogcyricsn_ouknu\&redir_esc $=\mathrm{y} \# \mathrm{v}=$ onepage\&q=the\%20other\%20 invisible\%2ohand\%2oremaking\%20charity\%2ofor\%2othe\%2021st\%2ocentury\&f=false. $\quad$ Retrieved on: May 8, 2019. Retrieved on: July 22, 2019.

Mullich, J. (2011). Corporate social responsibility emerges in China. The Wall Street Journal. Available at: http://online. wsj.com/ad/article/chinaenergy-responsibility. Retrieved on: May 7, 2019. Retrieved on: July 22, 2019.

Naimah, Z. (2017). The role of corporate governance in firm performance. SHS Web of Conferences, 34, 13003, EDP Sciences. Available at: https://sci-hub.tw/https://doi.org/10.1051/shsconf/20173413003. Retrieved on: May 10, 2019.

Ncell. (2019). About us: our CSR. Kathmandu: Ncell. Available at: https://www.ncell.axiata.com/AboutUs/CSR. Retrieved on: May 1, 2019.

Nepal Doorsanchar Company Limited. (2019). Quick links: corporate social responsibility. Kathmandu: Author. Available at: https://www.ntc.net.np/csr. Retrieved on: May 1, 2019.

NMB Bank Limited. (2019). About us: introduction. Kathmandu: Author. Available at: https://www. nmbbanknepal.com/about-us/introduction. Retrieved on: April 15, 2019.

Organization Economic Corporation and development (OECD). (2019). About: publishing. Paris: Author. Available at: http://www.oecd.org/about/publishing/. Retrieved on: May 9, 2019.

Olinsson, S. B. (2017). Social entrepreneurship: committing theory to practice. Journal of Social Entrepreneurship, 8(2), 225-247. Available at: https://www.tandfonline.com/doi/abs/10.1080/194206 76.2017.1375547. Retrieved on: May 12, 2019.

Page, J. P. (2005). Corporate governance and value creation. Research Foundation of CFA Institute. Available at: https://www.academia.edu/4636268/Corporate_Governance_and_Corporate_Social_Responsibility_Synergies_and_Interrelationships. Retrieved on: May 16, 2019.

Pathak, R. R., Poudel, B. R., \& Acharya, P. E. (2018). Social enterprise and social entrepreneurship: conceptual clarity and implication in Nepalese context. NCC Journal, 3(1), 143-152. Available at: https://www.nepjol.info/index.php/NCCJ/article/view/20256. Retrieved on: May 14, 2019.

Porter, M. E., \& Kramer, M. R. (2006). Strategy and society the link between competitive advantage 
and corporate social responsibility. Harvard Business Review, December, 2006, 78-92. Boston: Havard Business School. Available at: https://hbr.org/2006/12/strategy-and-society-the-link-between-competitive-advantage-and-corporate-social-responsibility. Retrieved on: January 18, 2019.

Raut, S. (2003). Corporate governance: concepts and issues. Institute of Directors, India. Available at: https://www.ingentaconnect.com/contentone/gse/bpcg1/2013/o0000001/ooooooo1/ artoooo6. Retrieved on: January 26, 2019.

Roberts, D., \& Woods, C. (2005). Changing the world on a shoestring: the concept of social entrepreneurship. University of Auckland Business Review, 7(1), 45-51. Available at: https://www.researchgate.net/profile/christine_woods/publication/242320433_changing_the_world_on_a_ shoestring_the_concept_of_social_entrepreneurship/links/oc96052afbd9a7929doooooo/ changing-the-world-on-a-shoestring-the-concept-of-social-entrepreneurship.pdf. Retrieved on: May 14, 2019.

Schwab, K., \& Sala-i-Martín, X. (2016, April). The global competitiveness report 2013-2014: full data edition. World Economic Forum. Available at: http://www3.weforum.org/docs/WEF_GlobalCompetitivenessReport_2012-13.pdf. Retrieved on: May 12, 2019.

Shah. K. K., (2012). Corporate social responsibility in Nepal. Academic Voices. Vol. 2. Available at: https:// www.nepjol.info/index.php/AV/article/view/8283. Retrieved on: March 30, 2019.

Surya Nepal Private Limited. (2019). Corporate social responsibility: SNPL Khelparyatan. Simara: Surya Nepal Pvt. Ltd. Available at: https://www.snpl.com.np/content/snpl-khelparyatan.html. Retrieved on: April 28, 2019.

The Villag Café. (2019). About us: the village café. Lalitpur: The Village Café. Available at: http://sabahnp.org/index.php?option=com_content\&view=article\&id=20\&Itemid=105. Retrieved on: April 25, 2019.

Three Sisters Adventure Trekking. (2019). About us: empowering women of Nepal. Pokhara: Author. Available at: https://www.3sistersadventuretrek.com/empowering-women-of-nepal. Retrieved on: May 12, 2019.

Van den Berghe, L., \& Louche, C. (2005). The link between corporate governance and corporate social responsibility in insurance. The Geneva Papers on Risk and Insurance-Issues and Practice, 30(3), 425442. Available at: https://link.springer.com/article/10.1057/palgrave.gpp.2510034. Retrieved on: May 14, 2019.

Vanhamme, J., \& Grobben, B. (2009). Too good to be true. the effectiveness of CSR history in countering negative publicity. Journal of Business Ethics, 85(2), 273. Available at: https://sci-hub.tw/ https://doi.org/10.1051/shsconf/20173413003. Retrieved on: May 13, 2019.

Vogel D (2006, July 28). The market for virtue the potential and limits of corporate social responsibility. (2nd revised ed.). Washington, D.C.: Brookings Institution Press. Available at: https://www.anzam. org/wpcontent/uploads/pdfmanager/1346_MAJUMDAR_NAZMUL-476.PDF. Retrieved on: January 18, 2019.

Waddock, S. (2004). Parallel universes: companies, academics, and the progress of corporate citizenship. Business and Society Review, 109(1), 5-42. Available at: https://onlinelibrary.wiley.com/doi/ abs/10.1111/j.0045-3609.2004.00002.x. Retrieved on: January 20, 2019.

Welzel, C. C. S. R. (2006). Corporate social responsibility in Nepal: a chance for peace and prosperity. Report Based upon a Mission to Nepal. Available at: https://www.emeraldinsight.com/doi/ abs/10.1108/14720701211275578?journalCode=cg. Retrieved on: May 11, 2019. 
Windsor, D., \& Preston, L. E. (1988). Corporate governance, social policy, and social performance in the multinational corporation. Research in Corporate Social Performance and Policy, 10(1), 45-58. Available at: http://57ef850e78feaed47e42-3eada556f2c82b951c467be415f62411.r9.cf2.rackcdn. com/wood-19910corporatesocialperformancerevisited.pdf. Retrieved on: May 12, 2019.

World Business Council for Sustainable Development, E. C. (2002). The business case for sustainable development: making a difference towards the earth summit 2002 and beyond. Corporate Environmental Strategy, 9(3), 226-235. Available at: https://www.sciencedirect.com/science/article/ pii/S1066793802000714. Retrieved on: May 10, 2019.

Ziyae, B. (2018). Presenting a model of corporate entrepreneurship with corporate governance approach. World Journal of Entrepreneurship, Management and Sustainable Development, 14(4), 342-352. Available at: https://www.sciencedirect.com/science/article/pii/S1066793802000714. Retrieved on: May 12, 2019. 